\title{
Rzekomy dokument Konrada mazowieckiego dla biskupstwa płockiego z 1203 roku*
}

\begin{abstract}
Zarys treści: Celem artykułu jest ustalenie, czy dokument Konrada mazowieckiego dla biskupstwa płockiego z 1203 r. jest falsyfikatem i kiedy został sporządzony. Analiza wykazała, że dokument powstał pod koniec XIV w., natomiast opisane w nim uposażenie biskupstwa płockiego pochodzi z początku XIII w.
\end{abstract}

Content outline: The purpose of the paper is to ascertain if the document of Konrad of Masovia is a forgery and when it was made. Its analysis showed that it was written up at the end of the $14^{\text {th }}$ century, while the possessions of the bishopric of Płock described in it come from the beginning of the $13^{\text {th }}$ century.

Słowa kluczowe: Konrad I mazowiecki, biskupstwo płockie, dyplomatyka, majątek i dochody biskupstwa

Keywords: Konrad I of Masovia, bishopric of Płock, diplomatics, estates and revenues of the bishoprics

\section{WSTĘP}

Dyplom Konrada I księcia Mazowsza i Kujaw, datowany na 1203 r. i potwierdzający majętności i dochody biskupstwa płockiego ${ }^{1}$, już od ponad wieku wzbudza zainteresowanie historyków. Nikt nie ma wątpliwości, że nie jest on autentyczny, ale co do tego, w jakich okolicznościach i kiedy go sporządzono, zdania są podzielone.

* Artykuł stanowi przeredagowaną wersję obronionej w 1998 r. pracy magisterskiej, przygotowanej na Wydziale Historycznym Uniwersytetu im. Adama Mickiewicza w Poznaniu pod kierunkiem prof. Tomasza Jasińskiego, któremu niniejszym składam podziękowania za pomoc i cierpliwość.

${ }^{1}$ Dokument jest własnością Archiwum Diecezjalnego w Płocku, sygn. 1, a przechowywany jest w płockim Muzeum Diecezjalnym. Nie są znane żadne jego kopie, transumpty ani wzmianki w innych średniowiecznych dokumentach. Wydany w: Kodeks dyplomatyczny Księstwa Mazowieckiego, wyd. J. Lubomirski, Warszawa 1863 (dalej cyt.: KDKM), s. 337 338; Castellaniae ecclesiae Plocensis, wyd. W. Kętrzyński, Monumenta Poloniae historica, t. V, Lwów 1886, s. 422-424; B. U l a n o w s k i, O uposażeniu biskupstwa płockiego, Rozprawy Akademii Umiejętności, Wydział Historyczno-Filozoficzny 21, 1888, s. 6-11, tamże, s. 399, jedyna jak dotąd reprodukcja (częściowa: lewy fragment pierwszych 8 wersów dokumentu); Zbiór ogólny przywilejów i spominków mazowieckich, t. I, wyd. J. Korwin Kochanowski, Warszawa 1919 (dalej cyt.: KDMaz.), nr 301, s. 342-348. Dalsze informacje o dokumencie podaje J. P i ęt ka, Fałszywe, niepewne i podejrzane dokumenty mazowieckie z pierwszej połowy XIII wieku, Przegląd Historyczny 88, 1997, z. 2, s. 293-294. 
Jak dotychczas historycy zajmowali się tym dokumentem przy okazji innych badań, dlatego ich opinie nie zawsze były do końca przemyślane i wyczerpujące.

Podejrzenia co do swej autentyczności dokument Konrada wzbudził już u swojego pierwszego wydawcy, Jana Lubomirskiego. Zauważył on, że pismo jest późniejsze i pochodzi najwcześniej z drugiej połowy XIII w., a i data budzi podejrzenia ${ }^{2}$. W latach osiemdziesiątych XIX w. Wojciech Kętrzyński odkrył w jednym z kodeksów płockiej biblioteki kapitulnej czternastowieczną notatkę zatytułowaną Iste sunt castellanie ecclesie Plocensis, wyliczającą wsie i dochody stanowiące uposażenie biskupstwa płockiego ${ }^{3}$; jej podobieństwo z uposażeniem opisanym w dokumencie Konrada z 1203 r. było uderzające. Odkrywca wyraził pogląd, że spis wsi i dochodów biskupstwa, nie licząc dwóch późniejszych darowizn, pochodzi z czasów jego fundacji, czyli z końca XI w., dokument Konrada zaś jest falsyfikatem z końca XIV w., o czym świadczy nieodpowiadające dacie pismo, ortografia polskich nazw miejscowych, nieużywane w XIII w. formuły kancelaryjne oraz niezgodność daty dokumentu z osobą odbiorcy, biskupa Guntera, a także ze świadkami ${ }^{4}$. Przeciwko uznaniu dokumentu za falsyfikat zaprotestował jednak Bolesław Ulanowski, który uznał go za „sporządzony jednostronnie przez któregoś z kanoników” w drugiej połowie XIII w. niedbały duplikat autentycznego dokumentu, wystawionego na prośbę biskupa Guntera, ale już po jego śmierci (w duplikacie przez pomyłkę opuszczono słowo olim). W zaginionym dzisiaj oryginale miał widnieć najpewniej rok 1239 , zgodny ze znanymi skądinąd świadkami, ale autor duplikatu przy przepisywaniu miał zgubić końcówkę daty. Zdaniem tego historyka dyplom ma prawidłowo przywieszoną pieczęć, w spisie wsi nie ma zaś tych nadanych po 1239 r. (a więc nie było powodu go fałszować w późniejszym czasie), pismo pochodzi z XIII w. i tylko błędy pisarza wywołują wątpliwości co do autentyczności ${ }^{5}$. Głos zabrał ponownie W. Kętrzyński, który nie uznał żadnego argumentu B. Ulanowskiego za autentycznością dyplomu za zasadny i podtrzymał swoje zdanie o sfałszowaniu dokumentu na przełomie

2 J. L u b o m irs ki, wydawca KDKM, s. 337-338, uważał też, że intytulacja, testacja i datacja zostały wpisane inną ręką niż reszta tekstu, ale jest to tylko wrażenie spowodowane wyraźnie ciemniejszym atramentem, a w przypadku datacji i testacji także mniej starannym, nierównym pismem; analiza poszczególnych liter wykazała ich wyraźne podobieństwo do liter z pozostałego tekstu. Uważam, że nawet jeżeli datacja i testacja miałyby zostać dopisane później, to przez tego samego pisarza.

3 Kodeks miał sygn. J.31 (której używali W. Kętrzyński i B. Ulanowski), a potem H.31 i MS 147; w czasie II wojny światowej został wywieziony przez Niemców i zaginął. W 2015 r. został zwrócony jego fragment, zawierający m.in. interesującą nas notatkę z uposażeniem biskupstwa - zob. A. S a l i n a, Z Jeny do Płocka. Powrót szczątków trzynastowiecznego kodeksu zrabowanego z Biblioteki Seminaryjnej, w: Stan badań nad wielokulturowym dziedzictwem Rzeczypospolitej (w druku), dziękuję Autorce za udostępnienie artykułu i skanu notatki. Notatka została wydana w całości i opisna przez W. Kętrzyńskiego (Castellaniae, s. 433-438). Nie są znane żadne jej kopie lub inne wersje, inne wydania ani reprodukcje. Tamże, s. 438, wydana także notatka Iste sunt ville capituli Plocensis ecclesie kathedralis - wykaz wsi należących do kapituły, o którym będzie mowa dalej. B. U l a n o w s k i, O uposażeniu, s. 6-11, publikując dokument Konrada, podał w przypisach również wszelkie różnice pomiędzy inwentarzem majątku biskupiego zamieszczonym w dokumencie, a tym opisanym w notatce w kodeksie.

${ }^{4}$ Castellaniae, s. 420-422.

${ }^{5}$ B. U l a n ow s k i, O uposażeniu, s. 13, 25, 26, 37. 
XIV i XV w. ${ }^{6}$ Za przekonanego przez Ulanowskiego uznał się natomiast Stanisław Krzyżanowski, dorzucając od siebie, że biskup Gunter mógł odpowiadać czasowi czynności prawnej (actum), świadkowie zaś sporządzeniu dokumentu (datum), przy czym rok 1203 pojawił się przez omyłkowe opuszczenie trzech cyfr rzędu dziesiątek (XXX) - dokument pochodziłby zatem z 1233 r., co odpowiadać może urzędowaniu biskupa Guntera ${ }^{7}$. Kolejny wydawca, Jan Korwin Kochanowski, po przeanalizowaniu argumentów za i przeciw autentyczności, uznał racje Kętrzyńskiego ${ }^{8}$. Nowy argument dorzuciła Zofia Kozłowska-Budkowa, uznając w 1939 r. pieczęć przywieszoną do tego dyplomu za falsyfikat sporządzony na wzór autentycznej pieczęci Konrada9. Z jej opinią zgodził się potem Stefan K. Kuczyński, uznając zarówno pieczęć, jak i cały dokument za „niewątpliwe falsyfikaty”" ${ }^{10}$. Do takich samych wniosków doszedł Henryk Łowmiański, wskazując na nieautentyczność eschatokołu i pieczęci, ale zaznaczając, że skoro spis majątku biskupstwa odpowiada pierwszej połowie XIII w., to trzon tekstu dokumentu musiał powstać w tym czasie, prawdopodobnie rzeczywiście z inicjatywy biskupa Guntera, lecz książę widocznie dokumentu nie zatwierdził. Na temat tego, kiedy mogło dojść do fałszerstwa i czy sam dyplom pochodzi z czasów Guntera, autor ten się nie wypowiedział ${ }^{11}$. Z kolei ks. Tadeusz Żebrowski wrócił do poglądów B. Ulanowskiego, uznając, że mamy do czynienia z pośpiesznie sporządzoną kopią oryginału wystawionego dla biskupa Guntera, w której omyłkowo zapisano rok 1203 zamiast 1239, który jest prawdopodobny, gdyż w tym właśnie czasie Konrad nadawał kościołowi płockiemu przywileje jako zadośćuczynienie za zabójstwo kanonika Jana Czapli ${ }^{12}$. Ostatniego podsumowania dyskusji dokonał Jan Piętka, uznając dokument za falsyfikat, powstały być może już w latach czterdziestych XIII w., choć sam dyplom jest zdecydowanie późniejszy ${ }^{13}$.

Opinie wszystkich historyków, którzy wypowiadali się na temat tego dokumentu, można sprowadzić do dwóch stanowisk: według jednych dokument jest falsyfikatem sporządzonym w XIV lub XV w., według innych - pełną błędów kopią autentycznego dokumentu Konrada I, przy czym sama treść jest jak najbardziej prawdziwa ${ }^{14}$. Uzasadniona jest zatem potrzeba rozwiązania problemu przez ponowną analizę wytoczonych przeciwko dokumentowi zarzutów dotyczących niezgodności daty

${ }^{6}$ W. K ę tr zy ń s k i, Dokument ks. Konrada Mazowieckiego z roku 1203, Przewodnik Naukowy i Literacki 15, 1887, s. 289-298, 385-394.

7 S. K r z y ż a n o w s k i, Początki dyplomatyki polskiej, Kwartalnik Historyczny 6, 1892, s. $806-808$.

8 KDMaz., s. 346-348.

9 Z. Kozłow ska-B udkowa, Pieczęć Konrada Mazowieckiego z roku 1223 i jej falsyfikat, Wiadomości Numizmatyczno-Archeologiczne 20, 1938-1939, s. 292-295.

${ }_{10}$ S. K. K u c z y ń s k i, Pieczęcie książąt mazowieckich, Wrocław 1978, s. 265-268.

${ }^{11}$ H. Ło o m i á s k i, Początki Polski, t. VI, Warszawa 1985, s. 355-357, przyp. 826.

12 T. Ż e brows ki, Uposażenie biskupstwa płockiego, w: Dzieje Mazowsza do 1526 roku Warszawa 1994, s. 134.

13 J. P i ęt k a, Fałszywe, s. 294.

${ }^{14}$ Za falsyfikat uznali ten dokument także F. P i e k o s i ń s k i, rec. artykułów W. Ketrzyńskiego, B. Ulanowskiego i S. Krzyżanowskiego, Kwartalnik Historyczny 1, 1887, s. 503-513; K. M y śli ń s k i, Najstarsza miejska historia Lubelszczyzny w świetle dokumentu Konrada Mazowieckiego z roku około 1239, w: Studia historyczne. Księga jubileuszowa profesora S. Arnolda, Warszawa 1965, s. 293-299. 
$\mathrm{z}$ wymienionymi w tekście osobami, osobliwości w dyktacie i formularzu, pieczęci, pisowni nazw miejscowych oraz ustalenie daty powstania zawartego $\mathrm{w}$ dokumencie inwentarza dóbr biskupich.

\section{DATA A WYMIENIONE W TEKŚCIE OSOBY}

W dokumencie zostało wymienionych pięć osób: wystawca (książę Konrad), odbiorca (biskup płocki Gunter) oraz trzech świadków.

Konrad I, syn Kazimierza Sprawiedliwego, panował na Mazowszu od ok. 1200 do 1247 r. Dokładna data objęcia przez niego rządów nie jest znana. W dokumencie z 1218 r. zapisano, że jest to dziewiętnasty rok jego panowania ${ }^{15}$. Dokument ten znany jest tylko z dużo późniejszej kopii, ale lata 1199-1200 jako termin podziału ojcowizny między Konrada i jego brata, Leszka Białego, są bardzo prawdopodobne. Ponieważ jednak Konrad urodził się w 1187 lub 1188 r. ${ }^{16}$, jest mało prawdopodobne, by już w latach 1199-1200 przyjechał na Mazowsze. Pierwszy jego znany niewątpliwie autentyczny dokument, wystawiony wraz z bratem Leszkiem, pochodzi dopiero z 1206 r. $^{17}$ Nie wiadomo więc, czy w 1203 r. przebywał w Płocku, ale jest to możliwe, skoro miał już wtedy około 15 lat.

W czasie długiego panowania Konrada I diecezja płocka miała siedmiu biskupów: Wita od 1187 do 1206, Gedkę od 1206 do 1223, Jana od 1223/1225 do 1227 (nie występuje on w żadnym współczesnym źródle, a znany jest tylko z Długosza), Guntera od 1227 do 7 III 1232, Piotra I w 1. 1232-1239/1240, Andrzeja I w 1. 1240-1244 i Piotra II w 1. 1245-1254 ${ }^{18}$. Odbiorca naszego dokumentu, biskup Gunter, władał diecezją dość krótko, ale właśnie w tym okresie biskupstwo płockie otrzymało od Konrada dwa przywileje dotyczące zwolnień z pewnych danin i służebności: pierwszy, bez daty, znany jest z papieskiego transumptu z 24 I 1232 r., drugi zaś zachował się w dwóch opieczętowanych oryginałach, wystawionych w Warce 7 XI 1231 r., różniących się nieznacznie treścią ${ }^{19}$.

Testacja w omawianym dokumencie Konrada brzmi: presentibus hiis testibus, Sveborio castellano de Siracz, iudice Nicholao, Lassota pincerna. Nie znamy żadnych pewnych urzędników księcia Konrada z 1203 r. ${ }^{20}$ W. Kętrzyński uznał za

${ }^{15}$ KDMaz. nr 200. Zachowany tekst ma pewne błędy, ale - jak twierdzi J. P i ę tk a, Fałszywe, s. 294-295 - treść nie budzi podejrzeń interpolacji czy fałszerstwa, choć nie można całkowicie wykluczyć jakiejś pomyłki przy kopiowaniu.

${ }^{16}$ O. B a 1 z e r, Genealogia Piastów, Kraków 1895, s. 262, 267; K. J a s i ń s k i, Rodowód Piastów małopolskich i kujawskich, Poznań-Wrocław 2001, s. 29-32.

17 Kodeks dyplomatyczny Wielkopolski, seria nowa, z. 1, wyd. Z. Perzanowski, Warszawa-Poznań 1975, nr 2. Zdaniem B. W ł od ar s k i e g o, Polityczne plany Konrada I księcia mazowieckiego, Toruń 1971, s. 7-8, Konrad przebywał jeszcze jakiś czas w Krakowie pod opieką matki Heleny, która zmarła między 1202 a 1206 r.

${ }_{18}$ J. M a c i e jew s ki, Episkopat polski doby dzielnicowej 1180-1320, Kraków-Bydgoszcz 2003, s. 244-248.

19 KDMaz. nr 278, 309-310.

${ }^{20}$ Poza słynnym wojewodą Krystynem, który mógł sprawować swój urząd już w 1203 r. $\mathrm{O}$ urzędnikach mazowieckich zob. J. P i ę t k a , Urzędnicy i otoczenie książąt mazowieckich, w: Społeczeństwo Polski średniowiecznej, t. I, Warszawa 1981, s. 128-160. 
autentycznego tylko jednego świadka, kasztelana sieradzkiego Wszebora ${ }^{21}$, jednak B. Ulanowski zwrócił uwagę na dokument Konrada wystawiony w Sieradzu 15 VI 1239 r., w którym występują wszyscy trzej świadkowie w tej samej kolejności. Dokument ten jest przywilejem immunitetowym dla dóbr katedry płockiej. Nie dochował się on niestety do naszych czasów w oryginale, lecz w dziesięciu kopiach i transumptach, pochodzących dopiero z XV i XVI w. ${ }^{22}$ Wszystkie kopie można sprowadzić do dwóch wersji dokumentu: w pierwszej wystawcą jest Konrad I, w drugiej jego syn - Bolesław I, poza tym są też między nimi pewne różnice w tekście, ale data i miejsce wystawienia pozostają te same. Jak dotąd tylko M. Łodyński przeanalizował dokładniej ten dokument ${ }^{23}$, dochodząc do wniosku, że obie wersje są efektem interpolacji i poprawek w tekście nieznanego dzisiaj oryginalnego dokumentu Konrada I z 1239 r., prowadzących do jego rozdwojenia. Zapis testacji w obu wersjach jest niejasny.

A (wersja z imieniem Konrada według transumptu z 17 I 1464 r.): Presentibus dilectis filiis meis duce Boleslao, Semouitho, Zemomislao ducibus et honorabili patre meo Fulcone Gnesnensi archiepiscopo, palatino Lanciciensi, Sweborio castellano de Syradz, iudice, Nicolao dapifero, Lassotha, Domangro thezaurario.

B (wersja z imieniem Bolesława w transumpcie z 1404 r.): Presente patre meo, duce Cunrado et fratribus meis, ducibus Semouito et Zemomislo et venerabili patre meo Fulcone Gneznensi archiepiscopo et pallatino Lanthciciensi, Sweborio castellano de Siracz, iudice, Nicolao dapifero, Lassota pincerna, Domangro thezaurario.

$\mathrm{W}$ pozostałych kopiach są jeszcze w testacji różnice w ortografii imion i przestawienia wyrazów, ale wszędzie brakuje imienia wojewody łęczyckiego i sędziego - zakładając, że sprawowany urząd podawano po imieniu, to imię Nicolao należy łączyć z dapifero.

Wszyscy trzej świadkowie z analizowanego dokumentu z 1203 r. występują też w innych dokumentach, ale już osobno. Kasztelan sieradzki Wszebor pojawił się jeszcze w przywileju dla klasztoru sulejowskiego, wystawionym przez Konrada i jego syna Siemowita w 1241 r. w Piotrkowie ${ }^{24}$. Także sędzia Mikołaj występuje poza tym tylko raz, w przywileju Bolesława I dla biskupstwa płockiego z $1241 \mathrm{r}^{25}$ Najczęściej pojawia się cześnik Lasota, świadczący w znanych z kopii przywilejach z 1232 i 1242 r. oraz w oryginale z 1246 r. Poza tym w 1247 r. L. pincerna nadał biskupstwu płockiemu wieś Żukowo, a dorsalna zapiska z XIV w. wyjaśnia, że darczyńcą był Lasota (de Zochouo quod dedit Lasota) ${ }^{26}$. Wszystkie powyższe

${ }^{21}$ Castellaniae, s. 421.

${ }^{22}$ KDMaz. nr 396; zob. B. U 1 a n ow s k i, O uposażeniu, s. 24; J. P i ę t k a, Fałszywe, s. 308 .

${ }^{23}$ M. Łodyń ski, Falsyfikaty wśród dokumentów biskupstwa płockiego w XIII w., Rozprawy Akademii Umiejętności, Wydział Historyczno-Filozoficzny 33, 1916, s. 159-174.

${ }^{24}$ KDMaz. nr 418, znany tylko z regestu; Urzędnicy łęczyccy, sieradzcy i wieluńscy XIII-XV wieku. Spisy, Wrocław 1985, s. 104.

${ }^{25}$ KDMaz. nr 410. Jest to falsyfikat (J. P i ęt k a, Fałszywe, s. 310), ale osoba świadka może być autentyczna. O mazowieckich sędziach zob. te n ż e, Urzędnicy, s. 137.

${ }^{26}$ KDMaz. nr 433 (uważany za falsyfikat), 437, 469, 473; zob. J. P i ę tk a, Urzędnicy, s. 136, 138, 141. Najprawdopodobniej cześnik Lasota jest identyczny z noszącymi to samo imię podkonim (1218-1232) i skarbnikiem książęcym znanym z lat czterdziestych XIII w. 
informacje dowodzą, że świadkowie dokumentu Konrada I z 1203 r. są postaciami autentycznymi, żyjącymi na przełomie lat trzydziestych i czterdziestych XIII w., ale tylko cześnik Lasota jest poświadczony przez dłuższy czas w otoczeniu Konrada.

Pojawienie się mało znanych świadków w tej samej kolejności na dwóch dokumentach dla tej samej instytucji jest bardzo interesujące i nasuwa przypuszczenie, że te dokumenty są ze sobą jakoś powiązane. Zauważyć można dalsze podobieństwa: charakterystyczna jest ortografia imienia Wszebor (Sveborius) z przestawieniem w obu wypadkach liter $s$ i $v$, podobny zapis nazwy Sieradza (Siracz) oraz postawienie funkcji Mikołaja przed jego imieniem. Ponieważ testacja wszystkich wersji przywileju Konrada z 1239 r. jest bogatsza o dwóch świadków (książąt i arcybiskupa nie licząc), to ona stanowić musiała podstawę, z której przepisano testację do dokumentu z 1203 r. Pominięto książąt i arcybiskupa, a także wojewodę łęczyckiego i stolnika, gdyż brakowało ich imion, a także skarbnika - być może z powodu jego podejrzanie dziwacznego imienia Domangerus ${ }^{27}$. Świadkowie nie tylko zostali więc przepisani z innego dokumentu, ale też nie jest prawdopodobne, by w 1203 r. pełnili już swoje urzędy.

\section{FORMULARZ}

Analizę formuł kancelaryjnych występujących w omawianym dyplomie utrudnia fakt, że dotąd nie ukazała się żadna praca poświęcona dokumentom księcia Konrada, ich cechom, nie określono też, które powstały w jego kancelarii, a które $\mathrm{u}$ odbiorcó $\mathrm{w}^{28}$. Zbadane zostały natomiast kancelarie książąt mazowieckich $\mathrm{z}$ lat 1248-138129 oraz funkcjonowanie kancelarii biskupów płockich w latach 12481357 i w późnym średniowieczu ${ }^{30}$. Dokumenty mazowieckie zostały wydane

${ }^{27}$ Być może jest to zniekształcony Doman; w 1218 r. znany jest podskarbi o takim imieniu (tamże, s. 136).

${ }^{28}$ Praca magisterska M. S y s k i, Dokumenty Konrada I mazowieckiego, Warszawa 1968, obroniona na Uniwersytecie Warszawskim, pozostała w maszynopisie i była dla mnie niedostępna. Znamy obecnie 71 dokumentów wystawionych przez Konrada I, w tym 8 interpolowanych oraz 17 falsyfikatów sporządzonych na jego imię - w sumie 25 dokumentów sfałszowanych w mniejszym lub większym stopniu (J. P i ęt k a, Repertorium dokumentów mazowieckich i Mazowsza dotyczących z XIII w. Koncepcja edycji, pierwsze problemy, Kwartalnik Historyczny 101, 1994, nr 3, s. 61-62).

${ }^{29}$ E. S u c h o d o l s k a, Kancelarie na Mazowszu w latach 1248-1345, Warszawa 1977; J. G r a b o w s k i, Kancelarie i dokumenty książąt mazowieckich w latach 1341-1381, Warszawa 1999. Aktualny stan badań nad kancelariami książęcymi na Mazowszu przedstawił t e n ż e, Kancelarie książęce na Mazowszu (XIII-XVI w.). Stan badań i perspektywy badawcze, w: Belliculum diplomaticum II Thorunense. Kancelarie władców na ziemiach polskich w średniowieczu i czasach nowożytnych na tle porównawczym, Toruń 2007; te n że, Kancelarie książęce na Mazowszu (do 1526 roku), w: Dyplomatyka staropolska, Warszawa 2015, s. 213-252.

${ }^{30}$ E. S u c h o d o 1 s k a, Kancelarie; J. G r a b o w s k i, Dokumenty i kancelaria Klemensa Pierzchały biskupa płockiego (1333/1337-1357), w: Kościół i państwo - wzajemne inspiracje i rywalizacja w dziejach, źródłach i studiach nad przeszłością, Warszawa 2008, s. 149-173; P. Ch o j n a c k i, Dokumenty i kancelaria biskupów płockich w późnym średniowieczu (1439-1522), niepublikowana praca doktorska obroniona na Uniwersytecie Warszawskim w 2005 r.; zob. też t e n ż e, Biskup płocki Paweł Giżycki (1439-1463) i jego działalność, 
zasadniczo w komplecie aż do $1381 \mathrm{r}^{31}$ i to one stanowić będą podstawę poniższych obserwacji.

Nawet bez specjalnych badań można jednak zauważyć, że dokumenty mazowieckie, zarówno z pierwszej, jak i z drugiej połowy XIII w., charakteryzują się dużą różnorodnością formuł kancelaryjnych, odmiennie niż w innych dzielnicach Polski, gdzie dominowała już rutyna ${ }^{32}$. Przeprowadzone przez Ewę Suchodolską badania nad formularzem dokumentów mazowieckich z lat 1248-1345 wykazały, że w XIII w. nie używano w tamtejszych kancelariach żadnych pomocy kancelaryjnych. Poszczególne wzory dyktatu pojawiały się i znikały wraz z konkretnymi urzędnikami. Często wykorzystywano brudnopisy wcześniejszych przywilejów lub oryginały dostarczane przez odbiorcę lub pisemną petycję odbiorcy. W dokumentach mazowieckich prawie nie występują arengi w czystej formularzowej postaci ${ }^{33}$. Dopiero w pierwszej połowie XIV w. w mazowieckich kancelariach książęcych wykształcał się jednolity styl. We wszystkich kancelariach pojawiać się zaczęły wtedy specyficzne dla Mazowsza cechy formularza, oparte najczęściej na przeróbkach obcych wzorów ${ }^{34}$. Obserwacja wydanych dotąd drukiem dokumentów mazowieckich prowadzi do następujących wniosków dotyczących formuł użytych w interesującym nas dokumencie.

Intytulacja Nos Cunradus dei gracia dux Mazovie Cuyavie nie pozwala wyciągnąć wniosków ani za, ani przeciw jego autentyczności. W swoich dokumentach Konrad raz używał liczby pojedynczej, a raz mnogiej, przy czym ta druga forma pojawiła się pierwszy raz w 1222 r., a przeważać zaczyna dopiero pod koniec lat trzydziestych ${ }^{35}$. Konrad tytułował się księciem Mazowsza i Kujaw do mniej więcej 1230 r., potem występował jako książę Mazowsza (na Kujawach rządził jego syn Kazimierz), a od 1234 r. jako książę łęczycki ${ }^{36}$ (Mazowsze odstąpił synowi Bolesławowi), ale czasami używał też nadal dawnego tytułu dux Mazovie et Cuyavie, np. w dokumencie z 1236 r. wyznaczającym granice synowskich dzielnic ${ }^{37}$.

Promulgacja presenti pagina ad universorum noticiam deducimus była zupełnie nieznana na Mazowszu w XIII i w pierwszej połowie XIV w. W ogóle promulgacje z czasownikiem deducere są w polskich dokumentach bardzo rzadkie. Na Mazowszu taki zwrot pojawił się po raz pierwszy w $1373 \mathrm{r}^{38}$, a kolejne na początku XV w.,

w: Z biografistyki Polski późnego średniowiecza, Warszawa 2001 (Fasciculi Historici Novi IV), s. 118-136.

${ }^{31}$ KDMaz. (do 1247 r.); Nowy kodeks dyplomatyczny Mazowsza, t. II-III, wyd. I. Sułkowska-Kuraś i S. Kuraś, Wrocław 1989 - Warszawa 2000 (dalej cyt.: NKDM); z kolei KDKM sięga aż do do końca XV w., ale jest mocno niekompletny i przestarzały.

${ }^{32}$ Zwrócił na to uwagę też S. K. K u c z y ń s k i, Pieczęcie, s. 62-63.

${ }^{33}$ E. S u c h o d o $1 \mathrm{~s} \mathrm{k}$ a, Kancelarie, s. 125-126 (charakterystyki kancelarii poszczególnych książąt na s. 56-57, 81-82).

34 Tamże, s. 115-116.

${ }^{35}$ KDMaz nr 212 (wystawiony w Trojanowie dla klasztoru w Czerwińsku, oryginał obecnie nieznany), 264 (z 1228 r. dla Krzyżaków i spisany przez nich), następne wystawione już po $1230 \mathrm{r}$.

${ }^{36}$ KDMaz. nr 350.

37 KDMaz. nr 361.

${ }^{38}$ NKDM III, nr 137, jest to jednak dokument znany z szesnastowiecznej kopii transsumptu z 1420 r., a 1373 r. nie zgadza się z pontyfikatem wystawcy, biskupa płockiego Dobiegniewa (1375-1381). 
jednak sformułowania identycznego z tym z dokumentu Konrada nie udało mi się znaleźć ${ }^{39}$.

Nietypowy dla XIII w. jest też użyty wobec biskupa tytuł reverendus in Christo. W XIII w. powszechnie określano biskupów przymiotnikiem venerabilis. Słowa reverendus in Christo pojawiły się na Mazowszu, w kancelarii biskupów płockich, dopiero w 1378 r. i do końca XIV w. wyparły tradycyjny zwrot venerabilis in Christo również w mazowieckich kancelariach książęcych ${ }^{40}$.

W żadnym wydanym drukiem zbiorze dokumentów mazowieckich nie udało mi się odnaleźć arengi identycznej lub choćby podobnej do użytej w dokumencie Konrada: qoud cum propter oblivionem, qui mater eroris est, tempestates gwerarum ac discursus et discursus ac vastaciones frequentes terrarum Christianorum per inimicos Christifidelium Jaczvangos et Prutenos ac alias gentes infideles, castra, predia, bona, ville, terre et possessiones quecumque sue ecclesie Mazoviensis et ad ipsam ecclesiam et ad ipsum racione ecclesie pertinencia, transcurso tempore propter defectum testimoniorum possent alienari vel aliquomodo distrahi. Nie pojawiły sie także osobno formuły: quod cum propter oblivionem, qui mater erroris est oraz transcurso tempore propter defectum testimoniorum possent alienari vel aliquomodo distrahi. Wyjątkowość ta odpowiada jednak trzynastowiecznemu zwyczajowi indywidualnego stylizowania każdej arengi.

Zdaniem W. Kętrzyńskiego w dokumentach z pierwszej połowy XIII w. niespotykana była rozbudowana formuła pertynencyjna: cum hiis villis, nemoribus, silvis, borris, pratis, venacionibus, piscaturis, fluviis et decursibus aquarum, którą uważał za charakterystyczną raczej dla XIV w., a szczególnie raził go tu wyraz borris ${ }^{41}$.

$39 \mathrm{~W}$ dokumentach księcia Janusza trzykrotnie wystąpiła promulgacja ad noticiam universorum presencium et futurorum deducimus (KDKM nr 142 [1402], 151 [1414], 160 [1423]), a podobna ad universorum tam presencium quam futurorum noticiam tenore presencium deducimus - trzykrotnie w dokumentach biskupów płockich (KDKM nr 143 [1402], 157 [1418], 182 [1438]) oraz w wyroku sądowym z 1405 r. w sprawie biskupa Jakuba z Kurdwanowa (KDKM nr 148). Podobne promulgacje występują także w dokumencie księcia Bolesława warszawskiego z 1432 i w dokumencie biskupim z 1472 r. (KDKM nr 170, 227). W piętnastowiecznej księdze formularzowej z Płocka znajdujemy formułę: universis et singulis tam presencium quam futurorum tenore presencium deducimus (Liber formularum ad ius canonicum spectantium, wyd. B. Ulanowski, Kraków 1892, s. 25, nr 15). Promulgacje z deducimus rzadko występowały także w kancelarii królewskiej, począwszy od czasów Elżbiety Łokietkówny, żadna jednak nie była identyczna z tą z dokumentu Konrada (I. S u łk o w s k a - K u r a s i o wa, Dokumenty królewskie i ich funkcja w państwie polskim za Andegawenów i pierwszych Jagiellonów 1370-1444, Warszawa 1977, s. 25, 47, 75).

${ }^{40}$ NKDM III, nr 207. Samo słowo reverendus w odniesieniu do biskupa pojawiło się po raz pierwszy na Mazowszu ok. 1279 r. w dokumencie sporządzonym w kancelarii biskupów płockich, a następnie w liście księżnej Kunegundy, żony Bolesława II płockiego z ok. 12921294 r. (NKDM II, nr 60, 97), potem zaś nie występuje do 1355 r. Nie biorę tu pod uwage nadania dla biskupa Chrystiana z 1222 r. z Lonyz, w którym wystąpił reverendus dominus Gethko episcopus Plocensis, gdyż dokument ten jest znany tylko z transumptów, pełnych różnych błędów, co wywołuje podejrzenie o fałszerstwo (J. P i ę tk a, Fałszywe, s. 296; T. J a s i ń s ki, Okoliczności nadania ziemii chełmińskiej Krzyżakom w świetle dokumentu łowickiego, w: Balticum. Studia z dziejów polityki, gospodarki i kultury XIII-XVII wieku ofiarowane Marianowi Biskupowi w siedemdziesiątą rocznicę urodzin, Toruń 1992, s. 151-163).

${ }^{41}$ Castellaniae, s. 421. 
B. Ulanowski starał się odeprzeć ten argument, przytaczając trzynastowieczne dokumenty, w których występowały rozbudowane formuły pertynencyjne ${ }^{42}$. Podane przez niego przykłady były jednak inaczej sformułowane - typowa dla XIII w. formuła brzmiała mniej więcej: cum agris, pratis, pascuis, aquis, campis, silvis i zwykle zawierała trzy lub cztery spośród wymienionych rzeczowników ${ }^{43}$. Oczywiście, zdarzały się czasami jakieś inne sformułowania, ale ze słowem borris nie spotkałam się wśród dokumentów sprzed połowy XIV w. Stylizacja tej formuły w naszym dokumencie jest zatem rzeczywiście podejrzana.

Koroboracja in cuius rei evidens testimonium nie była znana na Mazowszu w pierwszej połowie XIII w. Dopiero od 1254 r. w dokumentach sporządzanych w kręgu biskupów płockich pojawia się koroboracja in cuius (huius) rei testimonium, która upowszechniła się w drugiej połowie XIII w., a w stuleciu następnym dominowała już także w dokumentach książąt mazowieckich ${ }^{44}$. Sformułowanie takie, jak w dokumencie Konrada, ze słowem evidens, znalazłam po raz pierwszy dopiero $\mathrm{W}$ dokumencie z $1345 \mathrm{r}^{45}$

Również występujące w koroboracji sformułowanie nostro sigillo maiori muniri fecimus należy uznać za anachroniczne dla całego XIII w., gdyż zróżnicowanie pieczęci na większe i mniejsze lub sygnetowe pojawia się dopiero na przełomie XIII i XIV w. ${ }^{46}$ Natomiast podobne zakończenie koroboracji: presentem paginam nostro sigillo (sigilli nostri) fecimus roborari (munimine confirmamus, munimine fecimus roborari) było używane w kancelarii arcybiskupów gnieźnieńskich od 1232 r., w ciągu XIII w. zdobyło sobie ogromną popularność i w stuleciu następnym było powszechnie używane we wszystkich polskich kancelariach ${ }^{47}$. W innych dokumentach Konrada nie ma mowy o fizycznym przywieszeniu pieczęci, czego zapowiedź w kancelariach mazowieckich pojawia się dopiero w połowie XIV w.

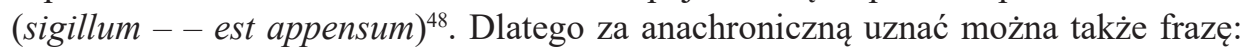
conscriptas appensionem [sic!] sigilli nostri ad perpetuum testimonium munire faceremus, zawartą we wcześniejszej partii dokumentu, gdy mowa o prośbie biskupa o potwierdzenie dóbr.

${ }^{42}$ B. U 1 a n ow s k i, O uposażeniu, s. 20.

${ }^{43} \mathrm{~W}$ dokumentach mazowieckich np. KDMaz. nr 433, 448, 472; NKDM II, nr 4, 104, 107, a także, już z XIV w., nr 133, 140, 226, 309.

${ }^{44}$ S. K. K u c z y ń s k i, Pieczęcie, s. 62-63. W NKDM II od 1254 r. do końca XIII w. znajduje się 7 dokumentów z taką koroboracją, która pojawiła się również w drugiej połowie XIII w. w kancelarii Leszka Czarnego (Z. M a z u r, Studia nad kancelarią Leszka Czarnego, Wrocław 1975, s. 88-89) i była powszechnie używana w kancelarii królewskiej w XIV i XV w. (I. S ułk ow s k a - K u r a s i ow a, Dokumenty, s. 13, 21, 37, 49, 50, 54, 76, 77).

${ }_{45}$ NKDM II, nr 267.

46 S. K. K u c z y ń s k i, Pieczęcie, s. 65-67, 269 przyp. 27; wskazał on też (s. 59-61), że koroboracja w dokumentach Konrada I jest bardzo różnorodna, ale daje się podzielić na dwa rodzaje: ,pozytywną”, rozpoczynającą się słowem ut, oraz „negatywną” z ne na początku; pojawienie się odmiennej koroboracji w dokumencie KDMaz. nr 301 jest, zdaniem tego historyka, jeszcze jednym dowodem jego nieautentyczności.

${ }^{47}$ F. S i k o r a, Dokumenty i kancelarie Przemysła I oraz Bolesława Pobożnego na tle współczesnej dyplomatyki wielkopolskiej, Wrocław 1969, s. 130, 141, 152.

${ }^{48}$ S. K. K u c z yń s k i, Pieczęcie, s. 68-69. 
Testacja otwierana słowami: presentibus hiis testibus należała do najczęstszych w XIII i XIV w., występowała powszechnie w kancelariach książęcych, kościelnych i królewskiej.

W rozważanym dokumencie Konrada I z 1203 r. występują więc elementy formularza niespotykane w trzynastowiecznych dokumentach mazowieckich. Jest to rozbudowana formuła pertynencji ze słowem borris, określenie pieczęci jako większej, promulgacja z deducimus, tytulatura biskupa reverendus in Christo i koroboracja in cuius rei evidens testimonium z zapowiedzią przywieszenia pieczęci. Cztery ostanie elementy formularza mogły pojawić się na Mazowszu w jednym dokumencie dopiero w ostatniej ćwierci XIV w.

\section{PIECZEĆ́}

Pieczęć Konrada I zachowana przy naszym dyplomie znajduje się do dziś dnia w dobrym stanie, przedstawia jeźdźca na koniu galopującym w prawo, trzymającego w prawej ręce krzyż równoramienny, a w lewej włócznię z dwustrefowym proporcem, w otoku znajduje się zaś napis majuskułą: + S. CONRADI DVCIS MAZOVIE ET CUIAVIE. Pieczęć jest prawidłowo przywieszona, ale znana jest z kilku dokumentów z lat dwudziestych XIII w., więc nie powinna zostać użyta ani w 1203 r., ani w latach trzydziestych. Dla W. Kętrzyńskiego był to kolejny argument za nieautentycznością dokumentu - uważał, że przewieszono ją zręcznie z innego dyplomu ${ }^{49}$. Dopiero Z. Kozłowska-Budkowa zauważyła, że pieczęć przy naszym dyplomie jest podrobiona $^{50}$. Opinię tę poparł S. K. Kuczyński, zdaniem którego pieczęć ta jest falsyfikatem prawdziwej pieczęci używanej przez Konrada I w latach ok. 1223-1228. Falsyfikat pieczęci, choć bardzo podobny, ma jednak widoczne różnice w stosunku do autentyku: odmienne rozmieszczenie liter oraz szczegółów w rysunku jeźdźca i konia. Pieczęć musiano więc odcisnąć za pomocą fałszywego tłoka ${ }^{51}$.

Konrad I posiadał kilka różnych pieczęci i co pewien czas je zmieniał. Nasuwa się pytanie, dlaczego fałszerz wybrał akurat tę pieczęć. Skoro uznano ją za najodpowiedniejszą, musiała pod jakimś względem pasować do treści dokumentu. Do XX w. zachowały się tylko dwa dokumenty Konrada I z oryginalnymi egzemplarzami tej pieczęci - niestety obydwa nie mają roku wystawienia. W pierwszym Konrad poświadczył oświadczenie biskupa płockiego Gedki (pełniącego swą funkcję w 1. 1206-1223?) w sprawie nadania Dobiechny dla kościoła Najświętszej Marii Panny w Płocku, drugi dotyczy dziesięcin dla biskupstwa płockiego, nie pada w nim imię biskupa, a datowany jest on na lata 1228-1232, kiedy biskupem płockim był Gunter ${ }^{52}$. Obydwa te dokumenty były przechowywane w archiwum kapituły płockiej, ale ten

${ }^{49}$ W. Kę tr z y ń s k i, Dokument, s. 280 n. Natomiast B. U 1 a n ow s k i, O uposażeniu, s. 13, 37, podtrzymywał opinię, że dokument jest duplikatem, przy którym zawieszono „niestosowną pieczęć”, gdyż właściwą pozostawiono przy oryginale, który później zaginął.

${ }^{50}$ Z. K o złow s k a - B u d k ow a, Pieczęć, s. 292-295.

${ }^{51}$ S. K. K u c z y ńs ki, Pieczęcie, s. 265-268, podaje dokładny opis oryginału pieczęci i jej falsyfikatu oraz informacje o zachowanych egzemplarzach, ich reprodukcjach i literaturze.

${ }^{52}$ KDMaz. nr 167, 267. S. K. K u c z y ń s k i, Pieczęcie, s. 266-268, przypuszczał, że taka sama pieczęć mogła wisieć jeszcze przy trzech zachowanych do dzisiaj dokumentach: nadaniu Krajka dla biskupa Chrystiana (bez daty), przy którym zachowały się jeszcze jej resztki; 
drugi wydaje się bardziej interesujący ze względu na fakt, że można go powiązać z osobą biskupa Guntera. Być może tradycja kościoła płockiego łączyła otrzymanie tego przywileju z biskupem Gunterem i dlatego właśnie tę pieczęć wykorzystano jako wzór do falsyfikatu. Przy tym przywilej regulujący problem dziesięcin był na tyle ważny i potrzebny, że nie zdecydowano się go pozbawić oryginalnej pieczęci w celu przewieszenia jej do falsyfikatu, co byłoby przecież dużo łatwiejsze i tańsze niż wykonywanie nowego tłoku pieczętnego. Możliwe jest także, że wzorem dla fałszerza był jakiś inny, dziś już nieistniejący, dokument z taką pieczęcią. Fakt, że taki fałszywy tłok musiano wykonać, wskazuje pośrednio na to, że falsyfikat sporządzono wiele lat po śmierci Konrada I. Gdyby bowiem duchowni płoccy preparowali ten falsyfikat już w XIII w., mogliby jeszcze znaleźć w swoim archiwum jakiś mniej ważny książęcy dokument i przewiesić jego pieczęć na nowy dyplom. $\mathrm{W}$ miarę upływu czasu nietrwałe pieczęcie ulegały zniszczeniu, więc znalezienie jakiegoś „niepotrzebnego” odcisku z odpowiednich lat stawało się już niemożliwe.

\section{PISMO I PISOWNIA NAZW MIEJSCOWYCH}

Obrońcy autentyczności dokumentu uważali jego pismo za trzynastowieczne ${ }^{53}$. Natomiast zdaniem W. Kętrzyńskiego pismo tylko dobrze naśladuje dukt trzynastowieczny, jest bowiem „niejednostajne”. Jako argument przeciwko autentyczności dyplomu przytoczył on także fakt, że pisarz nie znał rzeczy, o których pisał, a które człowiek żyjący w XIII w. znałby na pewno; świadczy o tym pisownia frustra zamiast frusta, ascripcii zamiast ascriptici, tunna zamiast cuna ${ }^{54}$.

Moim zdaniem pismo wyglada na pochodzące z XIV w. Jest czytelne, ale niezbyt staranne. Pewne litery, jak minuskulne $d, k, p$ oraz majuskulne $B$ i $N$, mają wyraźnie dwie wersje, a minuskulne $r$ - aż cztery. Nie ma niestety w polskiej litreraturze prac dotyczących historii pisma dokumentowego czy charakterystyki średniowiecznej ortografii łacińskiej ani opracowań pozwalających jednoznacznie datować kształt i sposób kreślenia danej litery ${ }^{55}$.

W. Kętrzyński zwrócił też uwagę na specyficzną, niepasującą do początku XIII w. pisownię nazw miejscowych $\mathrm{w}$ dokumencie ${ }^{56}$. Jej analizę ułatwia porównanie

potwierdzeniu nadania biskupa krakowskiego Iwona dla brata Wisława z 1223 r.; nadaniu Nieszawy Krzyżakom z 1230 r. (KDMaz. nr 225, 228, 297).

${ }_{53}$ B. U l a n o w s k i, O uposażeniu, s. 13, 24, F. P i e k o s iń s k i, rec., s. 505. S. K r z y ż a n o w s k i, Początki, s. 807-808.

${ }^{54}$ Castellaniae, s. 420-421. Jego zdaniem m.in. mieszają się kształty liter typowe dla XII, XIII i XIV w. (na przykład $t$ i $r$ ); niektóre litery są naśladowane $z$ dawnych bull papieskich; $y$ zapisano bez kresek lub z kreskami, często przez ii lub ij, co wskazuje na okres późniejszy niż XIII w.; zamiast zwykłego $i$ pisano podwójne ii (np. possessiiones, ascendiit); pojedyncze litery są czasem łączone.

${ }_{55}$ Zob. J. Grabow s ki, Kancelarie, s. 98. Rezygnuję ze szczegółowej analizy pisma i próby ustalenia pisarza dokumentu lub wskazania dokumentu, który był wzorem pisma dla fałszerza. Analiza taka wymagałaby rozległych kwerend w różnych archiwach.

${ }^{56}$ Castellaniae, s. 421. B. U la n ow s k i, O uposażeniu, s. 24, uważał, że nie ma to znaczenia, i podawał przykłady polskich nazw miejscowych zapisanych w XIII w. w sposób charakterystyczny dla XIV lub XV w. 
z zapisem tych samych nazw w innej wersji inwentarza dóbr biskupich znanej z czternastowiecznego kodeksu ${ }^{57}$. W obu wersjach inwentarza wymieniono w sumie 237 nazw miejscowych, z czego tylko 28 zapisano identycznie w obydwu wersjach, ale kolejnych 97 różni się tylko jedną lub dwiema literami, niemającymi wpływu na brzmienie nazwy: $v$ i $u$ lub $w$ oraz $i$ i $i i$ lub $y, s$ i ss, $k$ i $c, b$ i $p, t$ i $d, 39$ nazw różni się zaś formą końcówki ${ }^{58}$.

Ciekawe jest porównanie pisowni nazw, w których można pewnie znaleźć miękkie $r$, którego wymowa na przestrzeni XII-XV w. przekształciła sie w $r-\dot{z}^{59}$. Na szesnaście nazw z miękkim $r$ w ośmiu przypadkach w obu wersjach zapisano je jako $r$, a w ośmiu - w kodeksie jako $r$, a w dokumencie jako rz (Crzycosii, Novscvrzyme, Sdzymiirze, Vdrzyno, Wyssemyrze, Przymerze, Borzyseuice, Strzqua). W innych dwóch nazwach w dokumencie występuje $r z$, a w kodeksie zapisano je w odmienny sposób (Vendrzowo - Wendexouo i Ogorzelino - Ocoselino). Tylko w jednym przypadku w kodeksie występuje rz (Dyrzinino), w dokumencie zapisane jako rs (Dzirsimino), chodzi tu jednak najprawdopodobniej o miejscowość Dzierżenin (w XVI w. wieś o takiej nazwie należała do biskupstwa płockiego). Nazwy w dokumencie zapisano więc w czasie, gdy wymowa $r-\dot{z}$ miała dużo większy wpływ na pisownię, czyli później niż nazwy w kodeksie. Dodatkowo w dokumencie występuje 8 nazw z $d z$ i 11 z cz (oraz nazwisko Pomnanowicz), w kodeksie zaś $d z$ i $c z$ nie ma wcale, co także wskazuje na to, że ortografia polskich nazw w inwentarzu w kodeksie jest bardziej archaiczna.

Interesujące są także patronimiczne nazwy wsi z końcówką -icy, które zaczęły, jak się przyjmuje, zmieniać tę końcówkę na -ice od połowy XIII w., a od połowy XIV w. występują już tylko nazwy z końcówką -ice ${ }^{60}$. W dokumencie powstałym przed połową XIII w. końcówek -ice nie powinno więc być wcale lub powinny wystąpić sporadycznie. Tymczasem w dokumencie Konrada jest więcej nazw z końcówką -ice (13) niż z końcówką -ici (10). W stosunku do zapisów w kodeksie w 12 przypadkach końcówki -ici zamienione zostały na -ice, w jednym na -ica, w dwóch nastąpiła zamiana $\mathrm{z}$-vici na -vo i w jednym $\mathrm{z}$-ici na -icz. Wreszcie w 10 przypadkach $\mathrm{w}$ obu tekstach końcówki są zgodne $(-i c i)^{61}$. W sumie w inwentarzu w kodeksie jest 27 nazw

${ }^{57}$ Castellaniae; zob przyp. 3. Wydawca inwentarza, W. Kętrzyński, porównywał zapisy nazw z dokumentem Konrada, można więc zaufać dokładności jego odczytu. O notatce i kodeksie dokładniej będzie jeszcze mowa dalej.

${ }^{58}$ Pozostałe nazwy różnią się brzmieniem, ale we wszystkich przypadkach są do siebie podobne. W dokumencie brak 11 nazw w całości lub częściowo z powodu uszkodzenia pergaminu, a w kodeksie brak 9 nazw najprawdopodobniej omyłkowo pominiętych podczas przepisywania dwóch fragmentów tekstu i kilku pojedynczych nazw miejscowości (zauważył to już W. Kętrzyński - Castellaniae, s. 425-426). W 4 przypadkach mam wątpliwości, czy chodzi o nazwy miejscowe, czy o nazwy osobowe (Tworimyrici/Tuorimirici) lub o określenie ludności służebnej (Cucharios, Conary, Camerarii).

${ }^{59}$ Wymowa $r$-ż panowała już w XIV w., choć jeszcze przez cały ten wiek spotyka się pisownię polskich nazw i słów przez $r$ (Z. K l e m e n s i e w i c z, Historia języka polskiego, t. I, Warszawa 1961, s. 110).

${ }^{60}$ W. T a s z y c k i, Rzekomo patronimiczne nazwy miejscowe, w: tenże, Rozprawy i studia polonistyczne, Wrocław 1958, t. I, s. 206.

${ }^{61}$ Pominęłam 5 nazw, które nie mają swoich odpowiedników lub mają różne brzmienie w każdej z wersji. 
miejscowych z końcówką -ici i nie ma żadnej z końcówką -ice, z czego można wyciągnąć wniosek, że nazwy w tym spisie mają bardziej archaiczne formy, niż te same nazwy w dokumencie, a więc te ostatnie zostały zapisane później.

\section{POWSTANIE I DATACJA INWENTARZA UPOSAŻENIA BISKUPSTWA}

Wspomniana wyżej druga wersja inwentarza wsi i dochodów biskupstwa płockiego, niemal identyczna z inwentarzem w dokumencie Konrada z 1203 r., znana jest z kodeksu przechowywanego niegdyś w Bibliotece Kapitulnej w Płocku ${ }^{62}$. Najdokładniejszy opis tego kodeksu dał B. Ulanowski przy okazji wydania zawartych w nim statutów synodalnych ${ }^{63}$. Odzyskany ostatnio fragment tego kodeksu zawiera między innymi interesujacą nas notatkę opatrzoną nagłówkiem: Iste sunt castellanie ecclesie Plocensis, wyliczającą wsie należące do biskupstwa płockiego oraz dochody z ceł i gniazda sokole. Znajduje się ona na k. 5v, pod dokumentem księcia Bolesława II z 1279 r. Obok, na k. 6r, pod przywilejem immunitetowym Konrada z 1230 r., w którym wymieniony jest biskup Gunter, zapisano krótszą notatkę, zatytułowaną Iste sunt ville ecclesie kathedralis Plocensis, zawierającą wykaz wsi należących do katedry (lub kapituły) płockiej ${ }^{64}$. Notatek tych nie opatrzono niestety żadną datą ${ }^{65}$. Dalej na k. 6v zapisano przywilej Konrada wystawiony 7 XI 1231 r., opatrzony nagłówkiem: Privilegium optimum, w którym również występuje Gunter, a następnie przywileje tego księcia dla wsi scholasterii płockiej z 1241 r. oraz dla wsi biskupich Łąkie, Popłacin i Suchodół, bez daty i miejsca wydania ${ }^{66}$. Obie notatki

${ }^{62}$ Zob. przyp 3. Wszystkie cytaty z tej notatki podaję na podstawie skanu oryginału (zob. wyżej, przyp. 3), dlatego różnić się one mogą od form przytaczanych w literaturze.

${ }_{63}$ B. U 1 a n o w s k i, Synod prowincjonalny w Kamieniu, Kraków 1915, s. 7-13, 19-23; A. Vetulani, Średniowieczne rękopisy płockiej biblioteki katedralnej, Roczniki Biblioteczne 7, 1963, s. 391-393. Kodeks liczył 305 kart i zawierał 16 traktatów prawniczych, przepisy liturgiczne i synodalne, krótką modlitwę, genealogię książąt piastowskich, trzy bulle papieskie z XIII w., 36 rozmaitych dokumentów i listów z XIII i XIV w. związanych z biskupstwem płockim (w tym 13 przywilejów różnych książąt), spis dochodów i wsi należących do biskupstwa, spis wsi należących do kapituły oraz spis czynszów z dóbr pruskich biskupstwa płockiego z lat 1319-1326. Poszczególne teksty powstały niezależnie od siebie w różnym czasie, zostały zapisane różnymi rękami z XIII i XIV w. i rozmieszczone bez jakiegoś logicznego czy chronologicznego porządku. Najstarsze były dwa główne traktaty prawnicze, skopiowane najprawdopodobniej w 1. 1260-1280, najmłodsza zaś - genealogia książąt piastowskich, zredagowana w 1. 1360-1366 (W. D r e li c h a r z, Genealogia płocka. Źródła, funkcje i treści ideowe, w: Venerabiles, nobiles et honesti. Studia z dziejów społeczeństwa Polski średniowiecznej. Prace ofiarowane Profesorowi Januszowi Bieniakowi w siedemdziesiątą rocznicę urodzin i czterdziestolecie pracy naukowej, Toruń 1997, s. 449). Zdaniem W. Kętrzyń sk i e go (Castellaniae, s. 992-994), karta z tekstem genealogii sprawiała wrażenie przyciętej i wszytej już po oprawie kodeksu, która zatem mogła nastąpić już około połowy XIV w.

${ }^{64}$ Dokumenty wydane w: NKDM II nr 62 oraz KDMaz nr 278; notatka z uposażeniem kapituły została wydana i opisana przez Kętrzyńskiego razem z notatką z uposażeniem biskupstwa: Castellaniae, s. 438 (zob. przyp. 3). Lakoniczny nagłówek nie pozwala ustalić, kto dokładnie był właścicielem tych wsi.

${ }^{65}$ B. U 1 a n o w s k i, Synod, s. 9, uważał, że dokumenty skopiował autor glosy z 1284 r.

${ }^{66}$ Dokumenty wydane w: KDMaz. nr 309-310, 408, 381. 
z uposażeniem wniesiono innym pismem niż kopie dokumentów, co wskazuje na to, że dopisano je później w wolnym miejscu. Nie ma podstaw, by sądzić, że były one wcześniej powiązane jakoś z przywilejami Konrada I. Nie można też określić czasu wpisania tych notatek do kodeksu dokładniej niż na pierwszą połowę XIV w., być może jeszcze przed jego oprawą.

Nie ma żadnych źródeł informujących o dacie założenia biskupstwa płockiego ani o jego początkowym uposażeniu. W historiografii panuje jednak zgodna opinia, że biskupstwo ufundował Bolesław Szczodry ok. 1075 r. ${ }^{67} \mathrm{O}$ uposażeniu biskupstwa w XII w. nie zachowały się żadne bezpośrednie informacje. Nie wiadomo także, kiedy rozdzielono dobra biskupie i kapitulne, najstarsza wzmianka o odrębnym majątku kapituły pochodzi z 1187 r. ${ }^{68}$ Kolejne znane dziś dokumenty informujące o jakichś nadanych lub posiadanych przez biskupa i kanoników wsiach pochodzą dopiero z XIII w., jest ich niewiele i nie można na ich podstawie odtworzyć stanu posiadania biskupstwa płockiego w żadnym określonym momencie XIII-XV w. Inwentarze, zachowane w kodeksie i w dyplomie Konrada, są jedynymi, jakie się zachowały z okresu średniowiecza. Niestety, nie powstała dotąd żadna praca naukowa poświęcona historii uposażenia biskupstwa płockiego w średniowieczu. Dopiero źródła szesnastowieczne pozwalają w pełni odtworzyć majątek ziemski płockiego biskupstwa i kapituły ${ }^{69}$.

W. Kętrzyński i B. Ulanowski, datując powstanie inwentarza biskupstwa, starali się znaleźć w nim argumenty za trafnością swoich sądów o dyplomie Konrada z 1203 r. W. Kętrzyński wyraził opinię, że spis uposażenia biskupstwa został zredagowany w chwili fundacji biskupstwa płockiego, z wyjątkiem dopisku o dwóch późniejszych darowiznach $^{70}$. Z kolei zdaniem B. Ulanowskiego inwentarz powstał z inicjatywy biskupa Guntera, nie wcześniej niż w czwartym dziesięcioleciu XIII w., w celu uzyskania od księcia potwierdzenia posiadania wymienionych w nim majętności i dochodów ${ }^{71}$.

${ }^{67}$ J. D o b o s z, Monarchia i możni wobec Kościoła w Polsce do początku XIII wieku, Poznań 2002, s. 129-131; M. R. P a u k, Płock i Spira. Piastowska imitatio imperii na przełomie XI i XII wieku, w: Świat średniowiecza. Studia ofiarowane Profesorowi Henrykowi Samsonowiczowi, Warszawa 2010, s. 492-523. Na pewno biskupstwo istniało już na początku XII w., gdyż biskup płocki został wymieniony wśród biskupów polskich, którym Gall Anonim zadedykował swoją kronikę.

${ }^{68}$ C. D e p tu ła, Kościół płocki w XII w., Studia Płockie 3, 1975, s. 74. Autor ten miał pewnie na myśli dokument Kazimierza Sprawiedliwego rozsądzający spór o patronat nad kościołem św. Benedykta na korzyść kanoników płockich (KDMaz. nr 123).

${ }^{69}$ B. U l a n o w s k i, O uposażeniu, ogranicza się tylko do XIII w., a T. Ż e b r o w s ki, Uposażenie, jest mało szczegółowy.

70 Castellaniae, s. 420-422, 425. Jego zdaniem osoba przepisująca ten inwentarz do kodeksu korzystała $\mathrm{z}$ oryginalnego spisu majątku biskupstwa albo z kopii pochodzącej najpóźniej z pierwszej połowy XIII w, o czym świadczą archaiczne końcówki nazw miejscowych i ortografia, natomiast pisarz dokumentu Konrada korzystał z jakiejś późniejszej kopii. W. Kętrzyński zwrócił też uwagę, że w dokumencie jest nazwa miejscowości (Vlenc), której nie ma w kodeksie. Również F. P i e k o s iń s k i, rec., s. 511-512, uważał, że spisy uposażenia w kodeksie i w dokumencie Konrada miały wspólne źródło w jakiejś dawniejszej zapisce, ale mogły one zawierać także późniejsze nabytki.

${ }^{71}$ B. U l a n o w s k i, O uposażeniu, s. 38-41, 45-47. Jego zdaniem notatka w kodeksie powstała później niż dokument, gdyż najpierw musiał być dokument nadania, a dopiero potem 
Wydaje się jednak nieprawdopodobne, aby inwentarz w kodeksie pochodził ze znanego dziś dokumentu Konrada I, z jakiejś innej jego wersji albo z innego autentycznego dokumentu książęcego. Dlaczego bowiem do kodeksu, zawierającego kopie przywilejów książęcych, przepisano by tylko sam spis uposażenia, a nie pełen tekst dokumentu? Poza tym, skąd wziąłby się spis wsi należących do kapituły, którego nie ma w dokumencie? Natomiast inwentarz w dokumencie Konrada nie mógł zostać przepisany z notatki w kodeksie, gdyż zawiera 9 miejscowości, których w kodeksie nie było. Musiał więc istnieć jeszcze w XIV w. inny, prawdopodobnie dużo wcześniejszy, spis biskupiego majątku, który przepisano około połowy XIV w. do kodeksu i który - niezależnie od notatki w kodeksie - stał się też podstawą do sporządzenia dokumentu Konrada.

Moim zdaniem inwentarz ten nie powstał w chwili założenia biskupstwa płockiego ani nie jest efektem dopisywania kolejnych nabytków do spisu najstarszego majątku biskupstwa. Najstarszym elementem uposażenia są wymienione na początku cztery kasztelanie majątkowe: w Pułtusku, Brańsku (obecnie: Brańszczyk), Broku i Święcku, a ponieważ położone są daleko od Płocka, biskupstwo otrzymało też zapewne od razu kilka wsi w jego bliższej okolicy. Gdyby spis wymieniał miejscowości w porządku chronologicznym ich otrzymania, to miejscowości koło Płocka wymieniono by zaraz po kasztelaniach, a tak nie jest - najpierw pojawiają się wsie nad Wkrą, następnie te $\mathrm{z}$ okolic Wyszogrodu i dopiero potem te spod Płocka. Aż 37 wsi wymienionych w inwentarzu (na 73 położone na zachodnim Mazowszu poza kasztelaniami) biskupstwo posiadało w połowie albo w części, co wskazuje na drobne nadania osób prywatnych, które nie mogły nastąpić w tym samym czasie.

Być może przy sporządzaniu inwentarza korzystano z jakichś wcześniejszych notatek, ale robi on wrażenie zredagowanego z rozmysłem dla jakiejś osoby z zewnątrz. Możliwe, że planowano uzyskanie papieskiego lub książęcego zatwierdzenia uposażenia na piśmie. Taki spis majątku mógł być również przydatny w wypadku zmiany władcy księstwa lub introinizacji nowego biskupa.

Uposażenie biskupstwa płockiego można podzielić na dwie części: 1) majątek ziemski oraz 2) dochody z ceł i gniazda sokole. Z kolei spis majątku ziemskiego również składa się z dwóch części: z czterech kasztelanii biskupich z należącymi do nich wsiami oraz z listy wsi biskupich znajdujących się poza granicami tych kasztelanii, a rozrzuconych po całym północnym i zachodnim Mazowszu. Kasztelanie, które wymieniono w inwentarzu, to biskupie kasztelanie majątkowe - twór umożliwiający obdarzenie instytucji kościelnej dużym areałem ziemi wraz z uprawiającymi ją ludźmi. Pojawiły sie one prawdopodobnie na początku XII w. ${ }^{72}$ Nie wiemy, od

prywatne spisy majętności. Różnice między notatką w kodeksie i dokumentem thumaczył niestarannością kopisty tego ostatniego. Podobnie uważał S. K r z y ż a n o w s k i, Początki, s. 808-809. Wbrew opinii B. Ulanowskiego, tworzenie przez instytucje kościelne ,prywatnych” zapisek z wykazami majątków było w Polsce częste, a nawiązywało do rozpowszechnionych w południowych Niemczech libri traditionum i było zwyczajem starszym niż praktyka wystawiania dokumentów (T. J u r e k, Początki dokumentu polskiego, w: Dyplomatyka staropolska, Warszawa 2015, s. 72-74).

72 O kasztelaniach majątkowych zob. K. M o d z e l e w s k i, Chłopi w monarchii wczesnopiastowskiej, Wrocław 1987, s. 194-207; t e n ż e, Między prawem książęcym a władztwem 
kiedy biskupstwo płockie posiadało swoje kasztelanie majątkowe, a najwcześniejsza (poza naszym dokumentem) informacja o jednej z nich - kasztelanii pułtuskiej pochodzi dopiero z $1230 \mathrm{r}$. i nie pozwala na określenie, czy inwentarz powstał przed, czy po tym roku ${ }^{73}$. Przy ustalaniu czasu powstania inwentarza nie można również wykorzystać zawartych w nim informacji o dochodach biskupa z ceł i o gniazdach sokolich z powodu braku źródeł, z którymi można by je porównać.

Warto natomiast zwrócić uwagę na występujących w inwentarzu przypisańców (ascripticii). Termin ten, określający ludzi osobiście wolnych, ale na zawsze przypisanych do majątku swego pana, pojawił się w Europie w XII w. Pierwszy raz na ziemiach polskich użyto go w 1193 r., a następne wzmianki pochodzą już z XIII w. ${ }^{74}$ Jest więc mało prawdopodobne, by redakcja inwentarza dóbr biskupich, a przynajmniej jego fragmentu mówiącego o pobieraniu przez biskupa stróży i podymnego zarówno od wolnych, jak i od przypisańców, mogła nastąpić wcześniej niż w drugiej połowie XII w. W inwentarzu podano, że biskupstwo pobiera od mieszkańców swoich wsi w tych kasztelaniach stróżę i podymne, ale nie wspomina o zwolnieniach od innych danin i służebności na rzecz księcia. W 1214/1215 r. dobra biskupstwa płockiego zostały na mocy przywileju wydanego w Wolborzu zwolnione od powozu, przewodu, narzazu i nastawy ${ }^{75}$. Skoro nie ma o tym wzmianki w inwentarzu, musiał on powstać wcześniej, przed $1215 \mathrm{r}$.

W spisie uposażenia biskupstwa wymienieni są dwaj donatorzy: Krystyn Pomianowic i Bogusza Degnowic. Fragment tekstu mówi o nich następująco (według wersji z kodeksu): item iste pertinent ad ecclesiam de Suzola - - Voynouo cum villis ei pertinentibus additum a Cristino Pomnanouic, Coscouo, Lubotiny, Glosouo addite a Bogusa Degnouic. Wynika z niego, że Krystyn podarował biskupstwu Voynowo z przyległymi wsiami, a Bogusza - Coscouo, Lubotiny i Glosouo i że miejscowości te leżały w okolicach Zuzeli, położonej nad Bugiem na wschodnim Mazowszu. Można zidentyfikować pierwszą z tych osób. Zachował się oryginalny dokument z 1219 r., w którym Konrad I potwierdził umowę między kanonikami płockimi a Przybysławą wdową po komesie Krystynie synu Pomiana, będącą wówczas już żoną jakiegoś Mikołaja. Na podstawie tej umowy Przybysława zatrzymała w dożywocie wsie Gori, Zuchodol i Brodino, zapisane w testamencie przez Krystyna kapitule płockiej ${ }^{76}$. Jest

gruntowym, cz. II: Instytucja kasztelanii majątkowych Kościoła w Polsce XII-XIII w., Przegląd Historyczny 71, 1980, s. 449-480; M. R. P a u k, E. W ółk i e w i c z, Ministri enim altaris ministri curie facti sunt. Ottońsko-salicki „system” Kościoła Rzeszy i jego oddziaływanie w Europie Środkowej XI-XII wieku, w: Kościół w monarchiach Przemyślidów i Piastów, Poznań 2009, s. 105-138, zwł. s. 119-125, 137.

${ }^{73}$ KDMaz. nr 278.

${ }^{74}$ K. M o d z e l e w s k i, Chłopi, s. 212-213, przyp. 37.

75 KDMaz. nr 175, 185.

${ }^{76}$ KDMaz. nr 202. Na osoby tych donatorów zwrócił już uwagę W. Kętrzyńs ki (Castellaniae, s. 425), który uznał Krystyna Pomianowica za identycznego ze słynnym wojewodą mazowieckim Krystynem, zamordowanym z rozkazu Konrada I w 1217 r. Wiemy dziś jednak, że wojewoda Krystyn był synem Piotra i pochodził z rodu Łabędziów, wywodzącym się od Piotra Włostowica (J. B i e n i a k, Ród Łabędziów, w: Genealogia. Studia nad wspólnotami krewniaczymi i trerytorialnymi w Polsce średniowiecznej na tle porównawczym, Toruń 1987, s. 9-31). 
bardzo prawdopodobne, że to ten sam Krystyn, który podarował biskupstwu Voynovo, a więc darowizna musiała nastąpić przed 1219 r. Bogusza Degnowic nie występuje w znanych dokumentach mazowieckich, inwentarz jest jedynym świadectwem jego istnienia. Trudno też zidentyfikować jego ojca, acz rzadkie imię Degno występowało w Wielkopolsce i na Kujawach w XII i XIII w. ${ }^{77}$ Można więc stwierdzić tylko, że i Bogusza żyć mógł na przełomie XII i XIII w.

W inwentarzu wymieniono w sumie 228 miejscowości należących do biskupstwa płockiego, z których udało mi się zidentyfikować pewnie 106, a dalszych 26 prawdopodobnie. Wśród zidentyfikowanych pewnie jest tylko 70 miejscowości, które w XVI w. nadal należały do biskupstwa płockiego lub kapituły, a kolejnych 11 jest znanych z innych źródeł średniowiecznych jako własność biskupstwa lub kapituły, ale w XVI w. już nie istniały lub zmieniły właścicieli ${ }^{78}$.

Wśród miejscowości wymienionych w inwentarzu rzuca się w oczy obecność Dobrzynia. Na całym północno-zachodnim Mazowszu nie znalazłam innej miejscowości, którą można by wiązać ze źródłowym zapisem Dobrin. Chodzi więc najpewniej o Dobrzyń nad Wisłą, tym bardziej że w identycznej formie zapisano jego nazwę w pochodzących z 1228 r. dwóch oryginalnych dokumentach na rzecz Rycerzy Chrystysowych, którym książę Konrad nadał ten gród, a biskup Gunter dodał swą położoną obok wieś wraz z ostrowem ${ }^{79}$. Biskupstwo miało więc wcześniej posiadłość w Dobrzyniu i to ją wymienił inwentarz, który musiał zatem powstać przed $1228 \mathrm{r}$.

Pomocna może być obserwacja losów innych miejscowści, kórych identyfikacja nie jest jednak pewna. Carnov castrum cum ostrov pertinenti ad ipsum castrum zostało wymienione zaraz po Dobrzyniu i dwóch niezidentyfikowanych wsiach Scrobovice i Sastovice, a przed Jasieniem koło Płocka ${ }^{80}$. Gdyby założyć, że Carnov z inwentarza to identycznie zapisane w odnośnym dokumencie Czarnowo, nadane biskupowi Chrystianowi przez biskupa płockiego Gedkę w 1222 r., nie można by wytłumaczyć

77 Świadek o tym imieniu wystąpił w falsyfikacie mogileńskim (KDMaz. nr 69), a Paweł syn Degna znany jest z 1249 r. (Dokumenty kujawskie i mazowieckie przeważnie z XIII wieku, wyd. B. Ulanowski, Archiwum Komisji Historycznej, t. IV. Kraków 1887, s. 156, nr 9).

${ }^{78}$ Prawie połowy wsi nie udało sie zidentyfikować, co jest pewnie wynikiem przemian osadniczych na tych terenach, relokacji wsi, łączenia ze sobą osad i zmian nazw. Zrezygnowałam z prezentacji tutaj moich ustaleń dotyczących identyfikacji miejscowości z powodu braku miejsca. Pełne i pewne opracowanie historii uposażenia biskupswa płockiego w średniowieczu jest tematem na osobną pracę.

79 KDMaz. nr 265, 266.

${ }^{80}$ Na podstawie tego sąsiedztwa T. Ż e b r ow ski, Uposażenie, s. 135-136, odrzuca pomysł, by Carnov był tą samą miejscowością, którą jako Carnovo wraz z Papowem biskup płocki Gedko nadał biskupowi chełmińskiemu. Autor ten uważa, że gród Carnov leżał na terenie dzisiejszego Brudzenia nad Skrwą, a Scrobovice i Sastovice, to późniejsze biskupie Bądkowo oraz szlacheckie Bądkowo Jeziorne. Wszystkie te trzy miejscowości leżą rzeczywiście obok siebie, zmiana nazw też jest możliwa, ale po naniesieniu na mapę wymienionych w inwentarzu miejscowości leżących poza terenami czterech kasztelanii biskupich widać wyraźnie, że część wsi wymieniono bez jakiegoś geograficznego porządku, nie jest to więc argument do końca przekonujący. 
istnienia tej miejscowości w spisie wsi należących do majątku biskupstwa płockiego inaczej, niż przyjmując, że inwentarz sporządzono przed tym nadaniem, a więc nie później niż na początku lat dwudziestych XIII w. ${ }^{81}$

Inną zagadkę stanowi w inwentarzu Dretyno et cum lacu et cum appendentibus villis in Pomezania. W dokumencie Konrada nazwa jest częściowo nieczytelna z powodu dziury w pergaminie, można odczytać tylko Dte[......] et cum appendentibus villis [......]orariam. Nie tylko nie jest więc pewne, jak ta miejscowość się nazywała, ale także, gdzie leżała - na Pomorzu czy w Pomezanii. Informacje, że znajdowała się nad jakimś jeziorem i była ośrodkiem większej włości, niewiele mogą pomóc. Ani w ziemi dobrzyńskiej (na którą wskazywałoby sąsiedztwo z Ruźcem), ani w chełmińskiej nie udało mi się znaleźć żadnej pasującej miejscowości ${ }^{82}$. Jan Powierski uważał, że Dretyno to przeinaczone Svetino, czyli Świecie nad Drwęcą ${ }^{83}$, jest jednak mało prawdopodobne, by w obydwu wersjach inwentarza tak bardzo przekręcono tę nazwę. Wiadomo, że biskupstwo płockie posiadało Świecie w $1230^{84}$, a w 1239 r. Bolesław I potwierdził posiadanie tego grodu i 16 przynależnych do niego wsi ${ }^{85}$, z których jednak żadna nie pasuje do zapisu Dretyno. Omyłkowe pominięcie w inwentarzu majątku biskupstwa tak dużej posiadłości jest mało prawdopodobne, więc brak Świecia w wykazie miejscowości jest kolejnym argumentem za powstaniem inwentarza przed $1230 \mathrm{r}$.

W 1230 r. biskupstwo płockie otrzymało przywilej dla Radziejowa, choć nie określono w nim, czy miejscowość ta należała do biskupa, czy do kapituły ${ }^{86}$. Radziejowa nie ma jednak ani w inwentarzu dóbr biskupich, ani w spisie wsi kapituły jest to skądinąd ciekawe, gdyż nadać go miała kościołowi płockiemu jeszcze żona Krzywoustego, Salomea. Nie ma też w inwentarzu wsi biskupich Łąkie, Popłacin i Suchodół, leżących w ziemi łęczyckiej, które w latach 1238-1241 otrzymały przywilej od Konrada I, ani nieznanego skądinąd Sobieszyna, którego dwie trzecie Michał Spiciszowic zobowiązał się zwrócić biskupstwu w $1256 \mathrm{r}^{87}$ Inwentarz nie

${ }^{81}$ KDMaz. nr 217. Dokument ma datę 1222, ale jego oryginał się nie zachował, a przekazane w kopiach dwie wersje budzą podejrzenia o interpolację lub fałszerstwo; T. J a s i ń s k i, Okoliczności, s. 151-163, uważa, że obydwie są falsyfikatami powstałymi w 1240 r., opartymi jednak na autentycznych dokumentach z 1222 i 1228 r. Sam fakt nadania tych dwóch miejscowości nie budzi wątpliwości i musiał nastąpić przed 1227 r., kiedy Gedko z pewnością już nie żył.

${ }^{82}$ W. Kęt r z y ń s k i (Castellaniae, s. 443) uważał, że owo Dretyno (Dzetino) to dzisiejszy Działyń nad Drwęcą; B. U la n o w s k i, O uposażeniu, s. 42-44, proponował identyfikację z Dzidnem na Pomorzu koło Nakła, znanym jako własność arcybiskupstwa gnieźnieńskiego w 1300 r.; T. Ż e b r o w s k i, Uposażenie, s. 136, uważał, że chodzi tu o miejscowość Trąbin, położoną na północny zachód od Ruźca, nad jeziorem, ale nie podał żadnych argumentów za taką identyfikacją.

${ }_{83}$ J. P owierski, Dobra ostrowicko-golubskie biskupstwa włocławskiego na tle stosunków polsko-krzyżackich w latach 1235-1308, Gdańsk 1977, s. 34.

${ }^{84}$ KDMaz.nr 286; jest to oryginał niebudzący żadnych podejrzeń, nie wiem więc, dlaczego T. Ż e brow s ki, Uposażenie, s. 136, twierdził, że biskupstwo płockie w 1230 r. nie posiadało jeszcze Świecia.

${ }^{85}$ KDMaz. nr 378.

${ }^{86}$ KDMaz. nr 278.

${ }^{87}$ KDMaz. nr 381; NKDM II, nr 22. 
wymienia też żadnej miejscowości, która została dowodnie nabyta w latach 1240$1300^{88}$. Wykaz sporządzono więc na samym początku XIII w. i później nie był już uzupełniany ${ }^{89}$.

Brak w spisie posiadłości biskupich Świecia dowodzi, że inwentarz pochodzi sprzed 1230, obecność Dobrzynia wskazuje, że powstać musiał przed 1228, a Czarnowa że nawet przed 1222 r. (o ile rok jego nadania Chrystianowi jest miarodajny). Brak wzmianki o daninach wolborskich pozwala cofnać się przed 1215 r. Biskup Gunter nie mógł zatem przedstawić inwentarza w tej postaci Konradowi do zatwierdzenia, gdyż zestawienie było już nieaktualne, o czym książę musiał wiedzieć, samemu zaś biskupowi zależałoby przecież na potwierdzeniu posiadania wszystkich posiadłości, także nowo uzyskanego Świecia.

Jak dotąd historycy, piszący o dokumencie Konrada z 1203 r. i powiązaniach łączących go z inwentarzem z kodeksu MS 147, pomijali zupełnie spis wsi należących do kapituły. Tymczasem analiza znanych dzisiaj nadań na rzecz kapituły wskazuje, że spis ten również pochodzi z początków XIII w. Wśród wymienionych tam 25 wsi kapitulnych nie ma bowiem miejscowości, których nadania znamy z trzynastowiecznych dokumentów: Bresnic (Brzeźnica) w 1207 r. należała do kapituły ${ }^{90}$; Gori, Suchodol i Brodino przed 1219 nadane zostały przez Krystyna, a w 1227 r. przysądzone kapitule płockiej; Crampsco w 1227 r. należało do kościoła płockiego i zostało odstąpione klasztorowi w Miechowie; Cirnevici i Mistrevo (nad Bzurą) w 1241 r. należały do scholasterii płockiej; Zyromino i Celkouo zostały w 1247 r. nadane kapitule przez kanonika Piotra, Słup w 1254 r. nadany przez Żyrosława;

${ }^{88}$ KDMaz. nr 472 (predium Selkovo = Szelków), $473($ Zuchouo = Żukowo); NKDM II, nr 1 (Parzeń i źreb w Cieszkowie, Proszkowo), 7 (wieś Dobra i trzy źreby w Gromicach), 23 (Wielka Wkra), 40 (Wieski, Reczyn i źreb w Cieślach), 49b (Rakowo), 65, 69 (Gorzędziej na Pomorzu z okolicznymi wsiami), 67-68 (Piaski), 75 (Rafałowo), 82-86 (Orzechowo i 300 łanów w ziemi lubawskiej), 108 (Strzeszkowo), 109 (Radzikowo).

${ }^{89}$ Nieco zamieszania wprowadzają tylko trzy informacje o zamianach wsi między biskupstwem a książętami mazowieckimi. Z inwentarza można się dowiedzieć, że biskupstwo posiadało część wsi Minino, całe Lbovo i połowę wsi Dlusnovo. W 1248 r. Bolesław I nadał katedrze płockiej wieś Parzeń i źreb w Cieszkowie (niewymienione w inwentarzu) oraz połowę Dłużniewa i połowę Łbowa (NKDM II, nr 1). W posiadaniu biskupstwa było więc całe Dłużniewo i aż trzy połówki Łbowa. Jednak już w 1250 r. Siemowit I w zamian za połowy wsi Łbowo i Dłużniewo odstąpił biskupstwu wieś Dobra i trzy źreby w Gromicach, potwierdzając jednocześnie poprzednie nadanie wsi Parzeń i źrebu w Cieszkowie (NKDM II, nr 7). W 1299 r. Bolesław II odstąpił biskupowi w zamian za części we wsiach Dziarnowo, Łbowo i Minino części wsi Reczyn (brak jej w inwentarzu), Młodochowo (inwentarz wymienia pół tej wsi) i Sowoklęszcz (w inwentarzu figuruje cały) - NKDM II, nr 105. Młodochowo oraz Sowoklęszcz Maior i Minor należały później do kapituły płockiej, Łbowa i Minina nie udało mi się zidentyfikować, gdyż nie występują one później wśród posiadłości biskupstwa, Dłużniewo zaś było później własnością szlachecką. Informacje te nie wykluczają posiadania przez biskupstwo przed 1248 r. części Minina i Dłużniewa, problem stanowi Łbowo. Możliwe, że i tę wieś biskupstwo posiadało przed 1248 r. tylko w części. Nie mamy też dziś na pewno informacji o wszystkich zmianach własnościowych wsi i ich części, a niewątpliwie nie zawsze też zaznaczano w żródłach, czy chodzi o całą wieś, czy tylko o jej część.

${ }^{90}$ KDMaz. nr 169. Wieś Bresnicia pojawiła się również w dwóch falsyfikatach jako nadana klasztorowi benedyktynek w Staniątkach przez biskupa płockiego Andrzeja w $1242 \mathrm{r}$. (KDMaz. nr 420; zob. J. P i ęt k a, Fałszywe, s. 312). 
Solnikowo w 1257 r. nadane przez wojskiego Boguszę, a Powsin i Pieryszew nadane w 1258 r. przez Boguszę Miecławica ${ }^{91}$.

Spis wsi kapituły płockiej znany z kodeksu MS 147 musiał więc zostać sporządzony przed 1207 r., a ponieważ jest prawdopodobne, że inwentarz kapitulny i biskupi spiano w tym samym czasie, także powstanie tego ostatniego można cofnąć przed 1207 r. W tej sytuacji rok 1203, którym opatrzono falsyfikat sporządzony pod imieniem Konrada, wcale nie musiał być wymyślony bez żadnego uzasadnienia. Być może inwentarz, który skopiowano do kodeksu i do dokumentu Konrada I, był opatrzony właśnie taką datą roczną.

\section{PODSUMOWANIE}

Czas zestawić wyniki przeprowadzonych rozważań nad dokumentem księcia Konrada dla biskupstwa płockiego z datą 1203. Podany w dokumencie rok nie odpowiada ani osobie odbiorcy, biskupa płockiego Guntera (1227-1232), ani świadkom, którzy przepisani zostali zapewne z innego dokumentu, pochodzącego z 1239 r. Podanej dacie nie odpowiada też część formuł kancelaryjnych, z których niektóre znajdują analogie dopiero w ostatniej ćwierci XIV w. Pieczęć jest sfałszowana na wzór autentycznej pieczęci Konrada używanej w latach dwudziestych XIII w. Pismo robi wrażenie późniejszego naśladownictwa duktu trzynastowiecznego. Formy zapisu nazw miejscowych wskazują na cechy języka polskiego późniejsze niż połowa XIII w. Nie jest to więc na pewno autentyczny dokument, który wyszedł z kancelarii książęcej w 1203 r. Nie może to być też rodzaj kopii naśladowczej, sugerowany przez B. Ulanowskiego „niedbały” duplikat, sporządzony jakiś czas później na wzór nieistniejącego już dziś oryginału z 1239 r. Pomysłu takiego nie da się obronić nie tylko w świetle ustaleń wskazujących na późniejsze powstanie tego dokumentu. Hipoteza taka nie przywraca bowiem nawet zgodności z osobą odbiorcy (który w 1239 r. już dawno nie żył). Po co zresztą tworzono by taki duplikat, skoro posiadano oryginał? Jeżeli miał zaś czemuś służyć, to dlaczego wykonano go z tak kardynalnymi i kompromitującymi błędami, jak pomyłka w dacie o ponad 30 lat? Dlaczego tak niestaranny produkt przechowywano potem w archiwum zamiast oryginału? Tworzy to nierozwiązywalny splot sprzeczności logicznych. Przyjąć zatem trzeba, że do czynienia mamy z późnym falsyfikatem, powstałym nie wcześniej niż pod koniec XIV w.

Falsyfikat ten zawiera jednak jak najbardziej wiarygodne informacje o majątku biskupstwa płockiego z początku XIII w. Zamieszczony w dokumencie dokładny wykaz wsi i dochodów należących do biskupstwa odpowiada inwentarzowi znanemu z notatki zapisanej przed połową XIV w. w kodeksie MS 147, należącym do płockiej biblioteki kapitulnej. Obie wersje powstały z przepisania wspólnej podstawy. Badania spisów dóbr katedry płockiej (zarówno biskupstwa, jak i kapituły) wykazały, że powstały one przed 1207 r., niewykluczone, że pierwowzór rzeczywiście opatrzony był datą 1203, którą przepisano potem do falsyfikatu.

Pozostaje pytanie, dlaczego pod koniec XIV w. zdecydowano się na tworzenie falsyfikatu opisującego uposażenie sprzed prawie 200 lat. Spośród 228 miejsco-

${ }^{91}$ KDMaz. nr 202, 248, 249, 408, 474; NKDM II, nr 17, 30, 36. 
wości wymienionych w dokumencie jako należące do biskupstwa, tylko 70 można odnaleźć między majętnościami biskupstwa lub kapituły w XVI w. Uważam, że ważniejsza od wykazu poszczególnych wsi była zawarta na początku inwentarza informacja o posiadaniu przez biskupa czterech kasztelanii: pułtuskiej, brańskiej, brockiej i święckiej, które (jako klucze dóbr) pozostały jego własnością aż do czasów nowożytnych. Właśnie te dobra zostały zajęte przez książąt mazowieckich Janusza i Siemowita podczas konfliktu z kolejnymi biskupami płockimi, mianowanymi przez papieży, Maffiolem Lampugnanim i Jakubem z Kurdwanowa. Książę warszawski Janusz zajął gród w Pułtusku i przez trzy lata pobierał dochody z okolicznych wsi. Biskup Jakub przybył na Mazowsze w 1397 r. i rozpoczął swe urzędowanie od prób odzyskania dóbr i przywrócenia poboru dziesięcin od ludności. Z wyroku wydanego przez sąd arbitrażowy 5 X 1400 r. ${ }^{92}$ wynika, że pomiędzy książętami a biskupem istniały spory o granice posiadłości, dziesięciny i stacje książęce w dobrach kościelnych. Informacje o przebiegu tego konfliktu są niestety szczątkowe ${ }^{93}$. Choć nie ma o tym bezpośredniej wzmianki źródłowej, jest bardzo prawdopodobne, że biskup przedstawiał w tych sporach pisemne dowody swoich praw do spornych miejscowości. Pilnie szukano więc dokumentów opisujących dobra biskupstwa w możliwie dawnych czasach. Znana (gdyż kilkadziesiąt lat wcześniej przepisywana) stara lista posiadłości nie miała właściwej formy dyplomatycznej, więc aby ją nadać, trzeba było sporządzić fałszywy dokument. Pracę wykonano porządnie od strony technicznej, starając się naśladować dawne pismo i pieczęć. Dokument opatrzono datą 1203 (być może zaczerpniętą z pierwotnej listy dóbr), przypisano go dobrze znanemu księciu Konradowi I, jako odbiorcę wprowadzono biskupa Guntera, dla którego rzeczywiście wystawionych zostało kilka ważnych przywilejów, znajdujących się w katedralnym archiwum i skopiowanych do kodeksu obok inwentarza biskupstwa, świadków zaś przepisano z innego dokumentu z 1239 r. Co ciekawe, także ten ostatni dokument stał się obiektem manipulacji, a jego podfałszowana wersja wypłynęła po raz pierwszy w 1404 r. przy okazji sporu biskupa Jakuba z księciem Siemowitem IV ${ }^{94}$. Okoliczność ta, być może przypadkowa, umacnia hipotezę, że to właśnie Jakub Kurdwanowski był inicjatorem sporządzenia fałszywego dyplomu Konrada rzekomo z 1203 r.

\section{BIBLIOGRAFIA}

Balzer O., Genealogia Piastów, Kraków 1895.

Bieniak J., Ród Łabędziów, w: Genealogia. Studia nad wspólnotami krewniaczymi i trerytorialnymi w Polsce średniowiecznej na tle porównawczym, Torun 1987.

Chojnacki P., Biskup płocki Paweł Giżycki (1439-1463) o jego działalność, w: Z biografistyki Polski późnego średniowiecza, Warszawa 2001 (Fasciculi Historici Novi IV).

Chojnacki P., Dokumenty i kancelaria biskupów płockich w późnym średniowieczu (14391522), Warszawa 2005, maszynopis pracy doktorskiej obronionej na Uniwersytecie Warszawskim.

Deptuła C., Kościół płocki w XII w., Studia Płockie 3, 1975.

92 KDKM nr 87.

${ }^{93}$ Konflikty Janusza I z kolejnymi biskupami płockimi omawia A. S a lin a, Polityka książąt mazowieckich wobec władz Kościoła od początku XIV wieku do 1526 roku, Poznań 2011, s. 72-74, 154-162.

${ }^{94}$ KDKM nr 14; zob. J. P i ę t k a, Fałszywe, s. 308. 
Dobosz J., Monarchia i możni wobec Kościoła w Polsce do początku XIII wieku, Poznań 2002.

Drelicharz W., Genealogia płocka. Źródła, funkcje i treści ideowe, w: Venerabiles, nobiles et honesti. Studia z dziejów społeczeństwa Polski średniowiecznej. Prace ofiarowane Profesorowi Januszowi Bieniakowi w siedemdziesiątą rocznicę urodzin i czterdziestolecie pracy naukowej, Toruń 1997.

Grabowski J., Dokumenty i kancelaria Klemensa Pierzchały biskupa płockiego (1333/13371357), w: Kościół i państwo - wzajemne inspiracje i rywalizacja w dziejach, źródłach i studiach nad przeszłością, Warszawa 2008.

Grabowski J., Kancelarie i dokumenty książąt mazowieckich w latach 1341-1381, Warszawa 1999.

Grabowski J., Kancelarie książęce na Mazowszu (do 1526 roku), w: Dyplomatyka staropolska, Warszawa 2015.

Grabowski J., Kancelarie książęce na Mazowszu (XIII-XVI w.). Stan badań i perspektywy badawcze, w: Belliculum diplomaticum II Thorunense. Kancelarie władców na ziemiach polskich w średniowieczu i czasach nowożytnych na tle porównawczym, Torun 2007.

Jasiński K., Rodowód Piastów małopolskich i kujawskich, Poznań-Wrocław 2001.

Jasiński T., Okoliczności nadania ziemii chełmińskiej Krzyżakom w świetle dokumentu łowickiego, w: Balticum. Studia z dziejów polityki, gospodarki i kultury XIII-XVII wieku ofiarowane Marianowi Biskupowi w siedemdziesiątą rocznicę urodzin, Torun 1992.

Jurek T., Początki dokumentu polskiego, w: Dyplomatyka staropolska, Warszawa 2015.

Kętrzyński W., Dokument ks. Konrada Mazowieckiego z roku 1203, Przewodnik Naukowy i Literacki 15, 1887.

Klemensiewicz Z., Historia języka polskiego, t. I, Warszawa 1961.

Kozłowska-Budkowa Z., Pieczęć Konrada Mazowieckiego z roku 1223 i jej falsyfikat, Wiadomości Numizmatyczno-Archeologiczne 20, 1938-1939.

Krzyżanowski S., Początki dyplomatyki polskiej, Kwartalnik Historyczny 6, 1892.

Kuczyński S. K., Pieczęcie książąt mazowieckich, Wrocław 1978.

Łodyński M., Falsyfikaty wśród dokumentów biskupstwa płockiego w XIII w., Rozprawy Akademii Umiejętności, Wydział Historyczno-Filozoficzny 33, 1916.

Łowmiański H., Początki Polski, t. VI, Warszawa 1985.

Maciejewski J., Episkopat polski doby dzielnicowej 1180-1320, Kraków-Bydgoszcz 2003.

Mazur Z., Studia nad kancelarią Leszka Czarnego, Wrocław 1975.

Modzelewski K., Chłopi w monarchii wczesnopiastowskiej, Wrocław 1987.

Modzelewski K., Między prawem książęcym a władztwem gruntowym, cz. II: Instytucja kasztelanii majątkowych Kościoła w Polsce XII-XIII w., Przegląd Historyczny 71, 1980.

Myśliński K., Najstarsza miejska historia Lubelszczyzny w świetle dokumentu Konrada Mazowieckiego z roku około 1239, w: Studia historyczne. Księga jubileuszowa profesora S. Arnolda, Warszawa 1965.

Pauk M. R., Płock i Spira. Piastowska imitatio imperii na przełomie XI i XII wieku, w: Świat średniowiecza. Studia ofiarowane Profesorowi Henrykowi Samsonowiczowi, Warszawa 2010.

Pauk M. R., Wółkiewicz E., Ministri enim altaris ministri curie facti sunt. Ottońsko-salicki „system” Kościoła Rzeszy i jego oddziaływanie w Europie Środkowej XI-XII wieku, w: Kościół w monarchiach Przemyślidów i Piastów, Poznań 2009.

Piekosiński F., rec. artykułów W. Kętrzyńskiego, B. Ulanowskiego i S. Krzyżanowskiego, Kwartalnik Historyczny 1, 1887.

Piętka J., Fałszywe, niepewne i podejrzane dokumenty mazowieckie z pierwszej połowy XIII wieku, Przegląd Historyczny 88, 1997, z. 2.

Piętka J., Repertorium dokumentów mazowieckich i Mazowsza dotyczących z XIII w. Koncepcja edycji, pierwsze problemy, Kwartalnik Historyczny 101, 1994, nr 3.

Piętka J., Urzędnicy i otoczenie książąt mazowieckich, w: Społeczeństwo Polski średniowiecznej, t. I, Warszawa 1981.

Powierski J., Dobra ostrowicko-golubskie biskupstwa włocławskiego na tle stosunków polsko-krzyżackich w latach 1235-1308, Gdańsk 1977. 
Salina A., Polityka książąt mazowieckich wobec władz Kościoła od początku XIV wieku do 1526 roku, Poznań 2011.

Salina A., Z Jeny do Płocka. Powrót szczątków trzynastowiecznego kodeksu zrabowanego z Biblioteki Seminaryjnej, w: Stan badań nad wielokulturowym dziedzictwem Rzeczypospolitej (w druku).

Sikora F., Dokumenty i kancelarie Przemysła I oraz Bolesława Pobożnego na tle współczesnej dyplomatyki wielkopolskiej, Wrocław 1969.

Suchodolska E., Kancelarie na Mazowszu w latach 1248-1345, Warszawa 1977.

Sułkowska-Kurasiowa I., Dokumenty królewskie i ich funkcja w państwie polskim za Andegawenów i pierwszych Jagiellonów 1370-1444, Warszawa 1977.

Syska M., Dokumenty Konrada I mazowieckiego, Warszawa 1968, maszynopis pracy magisterskiej obronionej na Uniwersytecie Warszawskim.

Taszycki W., Rzekomo patronimiczne nazwy miejscowe, w: tenże, Rozprawy i studia polonistyczne, t. I, Wrocław 1958.

Ulanowski B., O uposażeniu biskupstwa płockiego, Rozprawy Akademii Umiejętności, Wydział Historyczno-Filozoficzny 21, 1888.

Ulanowski B., Synod prowincjonalny w Kamieniu, Kraków 1915.

Urzędnicy łęczyccy, sieradzcy i wieluńscy XIII-XV wieku. Spisy, Wrocław 1985.

Vetulani A., Średniowieczne rękopisy płockiej biblioteki katedralnej, Roczniki Biblioteczne 7, 1963.

Włodarski B., Polityczne plany Konrada I księcia mazowieckiego, Toruń 1971.

Żebrowski T., Uposażenie biskupstwa płockiego, w: Dzieje Mazowsza do 1526 roku Warszawa 1994.

\title{
The alleged document of Konrad of Masovia for the bishopric of Plock from 1203
}

\author{
Summary
}

The paper analyses the document of duke Konrad of Masovia, dated 1203 and confirming at the request of bishop Gunter the land estate and revenues of the bishopric of Płock. The year does not fit the time frame of Gunter as bishop of Płock (1227-1232) not the witnesses, known from the 1230's (most probably copied from a document of 1239). The seal was forged to resemble the authentic seal of Konrad used by him about 1223-1228. The analysis of the formulary shows that some of its elements do not appear in any $13^{\text {th }}$ century Masovian documents: the extended formula of pertinence, calling the seal greater, promulgation with deducimus, addressing the bishop as reverendus in Christo and corroboration in cuius rei evidens testimonium with the promise of attaching the seal. The last four elements of the formulary could appear in one document in Masovia only in the last quarter of the $14^{\text {th }}$ century. The analysis of the orthography of Polish place names with soft $r$ and $r-z$, as well as patronymic endings in place names indicates that they could not have been written in the first half of the $13^{\text {th }}$ century. On the other hand, the list of places belonging to the bishopric shows, that it was made at the beginning of the $13^{\text {th }}$ century, because it includes the villages of which the bishopric divested in the $13^{\text {th }}$ century, while excluding those, which it obtained. Also, there is no mention of the exemption of the bishop's estates from tributes and services, granted by the privilege issued in Wolbórz in 1214/1215. The document in question is therefore a forgery made at the end of the $14^{\text {th }}$ century, most probably at the order of the bishop of Płock Jakub of Kurdwanowo, during his conflict with the Masovian dukes. However the inventory of land estates included in it comes from the beginning of the $13^{\text {th }}$ century and may have been drawn up in 1203 . 